\title{
RESEARCH
}

Open Access

\section{Knockdown ATG4C inhibits gliomas progression and promotes temozolomide chemosensitivity by suppressing autophagic flux}

Zhi-peng Wen ${ }^{1,2,3}$, Wen-jing Zeng ${ }^{1,2,3}$, Yan-hong Chen ${ }^{1,2,3,4}$, He Li ${ }^{1,2,3}$, Jie-ya Wang ${ }^{1,2,3}$, Quan Cheng ${ }^{5}$ Jing Yu ${ }^{1,2,3}$, Hong-hao Zhou ${ }^{1,2,3}$, Zheng-zheng Liu ${ }^{6^{*}}$, Jian Xiao ${ }^{7^{*}}$ and Xiao-ping Chen ${ }^{1,2,3^{*}}$

\begin{abstract}
Background: Gliomas are the most common primary tumors in central nervous system. Despite advances in diagnosis and therapy, the prognosis of glioma remains gloomy. Autophagy is a cellular catabolic process that degrades proteins and damaged organelles, which is implicated in tumorigenesis and tumor progression. Autophagy related $4 C$ cysteine peptidase (ATG4C) is an autophagy regulator responsible for cleaving of pro-LC3 and delipidation of LC3 II. This study was designed to investigate the role of ATG4C in glioma progression and temozolomide (TMZ) chemosensitivity.

Methods: The association between ATG4C mRNA expression and prognosis of gliomas patients was analyzed using the TCGA datasets. The role of ATG4C in proliferation, apoptosis, autophagy, and TMZ chemosensitivity were investigated by silencing ATG4C in vivo. Ectopic xenograft nude mice model was established to investigate the effects of ATG4C on glioma growth in vivo.

Results: The median overall survival (OS) time of patients with higher ATG4C expression was significantly reduced (HR: 1.48, $\left.p=9.91 \times 10^{-7}\right)$. ATG4C mRNA expression was evidently increased with the rising of glioma grade $\left(p=2.97 \times 10^{-8}\right)$. Knockdown ATG4C suppressed glioma cells proliferation by inducing cell cycle arrest at G1 phase. ATG4C depletion suppressed autophagy and triggered apoptosis through ROS accumulation. Depletion of ATG4C suppressed TMZ-activated autophagy and promoted sensitivity of glioma cells to TMZ. Additionally, ATG4C knockdown suppressed the growth of glioma remarkably in nude mice.

Conclusion: ATG4C is a potential prognostic predictor for glioma patient. Targeting ATG4C may provide promising therapy strategies for gliomas treatment.
\end{abstract}

Keywords: Glioma, Glioblastoma, ATG4C, Autophagy, Temozolomide

\footnotetext{
*Correspondence: chenxiaoping@csu.edu.cn; admanoas@163.com; Izzsmile@aliyun.com

${ }^{6}$ Department of Oncology, Xiangya Hospital, Central South University, Changsha 410008, Hunan province, China

${ }^{7}$ Department of Pharmacy, Xiangya Hospital, Central South University, Changsha, Hunan 410008, People's Republic of China

'Department of Clinical Pharmacology, Xiangya Hospital, Central South

University, Changsha, Hunan 410008, People's Republic of China

Full list of author information is available at the end of the article
}

(c) The Author(s). 2019 Open Access This article is distributed under the terms of the Creative Commons Attribution 4.0 International License (http://creativecommons.org/licenses/by/4.0/), which permits unrestricted use, distribution, and reproduction in any medium, provided you give appropriate credit to the original author(s) and the source, provide a link to the Creative Commons license, and indicate if changes were made. The Creative Commons Public Domain Dedication waiver (http://creativecommons.org/publicdomain/zero/1.0/) applies to the data made available in this article, unless otherwise stated. 


\section{Background}

Gliomas are the most common primary malignant tumors of central nervous system (CNS) in adults $[1,2]$. According to the morphopathology features of tumor cells, gliomas are mainly classified into subtypes including astrocytoma, oligodendroglioma, ependymoma and choroid plexus papilloma [3, 4]. Based on pathological evaluation, gliomas are categorized as Grade I to IV, and higher grade indicates worse prognosis $[3,5]$. The median survival time of patients with low-grade glioma (LGG, Grade II and III) is 3 to 10 years, compared with 1.5 years for patients with Grade IV (Glioblastoma) [6-10]. Temozolomide (TMZ) is considered to be the most effective drug for the treatment of glioblastoma, which can prolong the survival of glioblastoma patients by 2 to 5 months $[9,11-13]$. Several molecular biomarkers, such as $I D H$ mutation, $1 \mathrm{p} / 19 \mathrm{q}$ co-deletion and $M G M T$ promoter methylation, are shown to predict prognosis and/or drug responses for gliomas [3, 9, 13]. However, the overall prognosis of gliomas has not been improved effectively.

Macroautophagy (Autophagy) is an evolutionally conserved dynamic catabolic process that degrades proteins and damaged organelles [14, 15]. The role of autophagy in tumorigenesis and progression is complicated. On the one hand, autophagy deficiency promotes tumorigenesis; on the other hand, autophagy is essential for the progression of tumor [16-21]. Additionally, recent studies have suggested that TMZinduced autophagy sustained the survival of glioblastoma cells, thereby contributing to drug resistance and recurrence [10, 22]. Blocking autophagy by inhibitor can significantly enhance TMZ cytotoxicity [23-25]. Whereas, non-specific autophagy inhibition may bring unexpected safety problems, which limits its clinical application [10, 26, 27].

The Cancer Genome Atlas (TCGA) project, aimed to depict profile of cancer genome, is widely used in tumor research. Based on TCGA data mining, we observed that expression level of autophagy related $4 \mathrm{C}$ cysteine peptidase (ATG4C), a member of ATG4 family, is deeply associated with prognosis of glioma patients. ATG4C is a cysteine peptidase responsible for lipidation and delipidation of LC3 during autophagy $[28,29]$. Previous study has shown that ATG4C is involved in the maintenance of stem-like phenotype in breast cancer cells [30]. However, the role of ATG4C in gliomas progression and TMZ chemosensitivity remains unclear.

In this study, we tried to determine whether interference with ATG4C can affect autophagy activity and TMZ sensitivity in glioma cell lines, as well as its role in disease progression of glioma both in vitro and in vivo.

\section{Methods}

Patients samples

Glioma was diagnosed according to the 2016 WHO Classification of Tumors of the Central Nervous System. The glioma tissues and clinical data were obtained from patients who underwent surgery between 2015 June and 2018 January at Xiangya Hospital of Central South University. The informed consents were provided to all patients or their family members. This study was approved by Central South University Xiangya Hospital Medical Ethics Committee.

\section{Bioinformatic data mining}

The integrated gliomas expression profile data and corresponding clinical data were downloaded from the TCGA database (http://www.cbioportal.org/study.do?cancer_study_id=lgggbm_tcga_pub). Clinical characteristics of the patients were shown in Table 1.

\section{Cell culture}

The human glioma cell line U87-MG was purchased from Cell Bank of Chinese Academy, Shanghai Institute of Biochemistry and Cell Biology, China Academy of Science. Human glioma cell line T98G was kindly provided by Dr. Lv from Jiangxi Cancer Hospital, China. The cell lines were identified using short tandem repeat (STR) markers. Cells were cultured in Dulbecco's modified Eagle's medium (DMEM) (Gibco, CA, USA) supplemented

Table 1 Baseline clinical characteristics of patients

\begin{tabular}{|c|c|c|c|}
\hline $\begin{array}{l}\text { Clinical } \\
\text { characteristic }\end{array}$ & $\begin{array}{l}\text { Prognosis analysis } \\
\text { in gliomas }\end{array}$ & $\begin{array}{l}\text { Prognosis } \\
\text { analysis in LGG }\end{array}$ & $\begin{array}{l}\text { Prognosis } \\
\text { analysis in GBM }\end{array}$ \\
\hline NO. of patients & 975 & 414 & 561 \\
\hline \multicolumn{4}{|l|}{ Age (years) } \\
\hline$\geq 55$ & 546 & 326 & 220 \\
\hline$<55$ & 429 & 88 & 341 \\
\hline \multicolumn{4}{|l|}{ Gender } \\
\hline Male & 573 & 227 & 346 \\
\hline Female & 402 & 187 & 215 \\
\hline \multicolumn{4}{|l|}{ WHO grade } \\
\hline$\|$ & 198 & 198 & 0 \\
\hline III & 216 & 216 & 0 \\
\hline IV & 561 & 0 & 561 \\
\hline \multicolumn{4}{|l|}{ IDH status } \\
\hline Wild & 483 & 77 & \\
\hline Mutant & 372 & 337 & \\
\hline Undefined & 120 & 2 & \\
\hline \multicolumn{4}{|l|}{ MGMT status } \\
\hline Unmethylated & 280 & & 211 \\
\hline Methylated & 514 & & 169 \\
\hline Undefined & 181 & & 181 \\
\hline
\end{tabular}


with $10 \%$ fetal bovine serum (FBS) (Gibco, CA, USA) in a humiliated incubator containing $5 \% \mathrm{CO}_{2}$ at $37^{\circ} \mathrm{C}$.

\section{Cell transfection}

Three different small interfering RNA (siRNA) against $A T G 4 C$ and negative control siRNA were synthesized by RiboBio (Guangzhou, China). Exponentially growing cells were seeded in 6 well plates and cultured overnight. The plated cell at $60-70 \%$ confluence was transfected with indicated siRNAs at a final concentration of $50 \mathrm{nM}$ using Lipofectamine RNAiMAX reagent (Invitrogen, CA, USA) following the manufacturer's instruction. The plasmid of RFP-GFP-LC3B was kindly provided by Professor Cheng, Central South University, China. Cells were transfected with $1.0 \mu \mathrm{g}$ plasmid per well of a 6-well plate using Lipofectamine 3000 reagent (Invitrogen, CA, USA) according to the manufacturer's instruction. Six hours after transfection, the medium was replaced with fresh medium containing 10\% FBS. The transfected cells were collected for further analysis.

\section{Lentivirus infection and stable cell lines establishment} The knockdown lentivirus vector of ATG4C (LV-ATG4CshRNA) and the lentivirus vector carrying scramble sequences (LV-NC-shRNA) were purchased from Genechem (Shanghai, China). All the lentivirus vectors were verified by DNA sequencing. After seeded in 6-well plates for $24 \mathrm{~h}$, cells were infected with ATG4C sh-RNA (sh-ATG4C) or negative control sh-RNA (sh-NC) at a multiplicity of infection (MOI) of 10 in the Opti-MEM medium. The culture medium was replaced with DMEM containing 10\% serum $12 \mathrm{~h}$ after, and cells were continually cultured in incubator at $37{ }^{\circ} \mathrm{C}$ with $5 \% \mathrm{CO}_{2}$. To establish ATG4C stable knockdown cell lines, infected cells were treated with puromycin $(2 \mu \mathrm{g} / \mathrm{ml}$ for U87-MG, $1 \mu \mathrm{g} / \mathrm{ml}$ for T98G) for 7 days. The knockdown efficiency was evaluated by Western blot analysis.

\section{Total RNA extraction and real-time qPCR}

Total RNA was extracted from tissues or cells using RNAiso Plus reagent (Takara, China) and then reversetranscribed to complementary DNA (cDNA) by PrimeScript RT Master Mix (Takara, China) according to the manufacturer's instruction. Real-time PCR was performed with LightCycler 480 type II instrument (Roche, Switzerland). PCR were conducted using the following cycling parameters: pre-denaturation at $95^{\circ} \mathrm{C}$ for $30 \mathrm{~s}$, followed by 45 cycles of two step: $95^{\circ} \mathrm{C}$ for $5 \mathrm{~s}$ and $60^{\circ} \mathrm{C}$ for $20 \mathrm{~s}$. GAPDH was selected to normalize genes expression levels using the $\Delta \Delta \mathrm{Ct}$ method. Primers used in this study were shown as Additional file 5: Table S1 (Ribobio, China).

\section{Western blot analysis}

The whole-cell lysates were produced by RIPA buffer containing PMSF. The protein concentrations were quantified using BCA Protein Assay kit (Beyotime, China). Equal amounts of proteins were added to SDS-PAGE and then transferred onto PVDF membrane. Blots were blocked in TBST buffer containing $5 \%(\mathrm{~m} / \mathrm{v})$ nonfat milk at room temperature for $2 \mathrm{~h}$ and then incubated at $4{ }^{\circ} \mathrm{C}$ overnight with primary antibodies as follows: GAPDH (Protein Tech), ATG4C (Abcam), LC3 (Cell Signaling Technology), P62 (Cell Signaling Technology), p21 (Ab clonal), p53 (AB clonal), Cyclin E (Cell Signaling Technology), Bcl-2 (Protein Tech), BAX (Protein Tech) and PARP (Protein Tech). After washing with TBST buffer, the membranes were probed with secondary antibodies (Invitrogen, USA) at room temperature for $1 \mathrm{~h}$. Immunoreactive binding was detected with BeyoECL star kit (Beyotime, China) using Bio-Rad ChemiDoc XRS imaging system (Bio-Rad, USA).

\section{Cell proliferation and viability assay}

Cell proliferation and viability were detected by MTS. Briefly, cells were seeded in 96-well at a density of 1000 cells/well. After culturing for indicated time, the medium was replaced with $100 \mu \mathrm{L}$ DMEM containing $10 \mu \mathrm{L}$ MTS (Promega, CA, USA) and incubated at $37^{\circ} \mathrm{C}$ for $1 \mathrm{~h}$. Then, the optical density (OD) values were detected at $490 \mathrm{~nm}$ using multi-well spectrophotometer. The survival rate was calculated as $\mathrm{AT}_{490} / \mathrm{CT}_{490} \times 100 \%\left(\mathrm{AT}_{490}=\right.$ Absorbance value of the experimental group at 490 $\mathrm{nm} ; \mathrm{CT}_{490}=$ Absorbance value of the control group at $490 \mathrm{~nm}) . \mathrm{IC}_{50}$ values were derived by GraphPad Prism 5 software through plotting the survival rates on a logarithmic curve.

\section{Colony forming assay}

After transfection, cells were dissociated and seeded in $3.5 \mathrm{~cm}$ dishes at a destiny of $1.0 \times 10^{3}$ cells/well and then cultured for 14 days. The cells were fixed with $4 \%(\mathrm{v} / \mathrm{v})$ formaldehyde for $15 \mathrm{~min}$, then stained with $0.1 \%(\mathrm{w} / \mathrm{v})$ crystal violet for $10 \mathrm{~min}$. After washing with PBS for three times, the number of colonies was counted.

\section{Cell cycle analysis}

Briefly, cells were harvested and fixed overnight in a freezer at $-20^{\circ} \mathrm{C}$ with precooled $70 \%$ ethanol, then centrifuged at $1000 \mathrm{~g}$ for $5 \mathrm{~min}$. The pellet was resuspended with $100 \mu \mathrm{L}$ PBS containing $2 \mu \mathrm{L}$ of RNase A $(10 \mathrm{mg} / \mathrm{mL})$, then incubated at $37^{\circ} \mathrm{C}$ for $30 \mathrm{~min}$. After that, $400 \mathrm{uL}$ of PBS including $20 \mathrm{uL}$ of PI $(1 \mathrm{mg} / \mathrm{mL})$ and $0.4 \mu \mathrm{L}$ of Triton- $\mathrm{X}$ were added and incubated at $37^{\circ} \mathrm{C}$ for $30 \mathrm{~min}$. The cell cycle distribution was analyzed flow cytometer (Beckman Coulter, USA). 


\section{Cell apoptosis assay}

Cells apoptosis was evaluated by Annevin V-FITC/PI and Hoechst 33342 staining. For Annevin V-FITC/PI staining, cells were dissociated by trypsin without EDTA and centrifuged at $1000 \mathrm{~g}$ for $5 \mathrm{~min}$. The pellet was resuspended with staining solution containing $5 \mu \mathrm{L}$ Annexin V-FITC and $10 \mu \mathrm{L}$ PI, then incubated at room temperature for $20 \mathrm{~min}$ in dark. The apoptosis was analyzed by flow cytometer following manufacture's instruction (Beyotime, China). For Hoechst 33342 staining, cells were fixed by $4 \%(\mathrm{v} / \mathrm{v})$ formaldehyde for $10 \mathrm{~min}$ and washed with PBS, then staining buffer with Hoechst 33342 were added. The apoptotic cells were observed under fluorescence microscope. For Caspase-3/6/9 activity assay, cells were harvested and centrifuged at $1000 \mathrm{~g}$ for $5 \mathrm{~min}$, and then incubated with lysis buffer for 15 min on ice. The lysate was centrifuged at $12000 \mathrm{~g}$ for 15 $\mathrm{min}$. Then the supernatant was detected for the caspase3/6/9 activity by multi-well spectrophotometer, according to the manufacture's instruction (Beyotime, China).

\section{Determination of ROS in cultured cells}

After transfection, T98G cells were harvested and centrifuged at $1000 \mathrm{~g}$ for $5 \mathrm{~min}$. The pellet was resuspended with DMEM containing DCFH-DA $(10 \mu \mathrm{M})$ and incubated for $20 \mathrm{~min}$. After that, the cell suspension was centrifuged at $1000 \mathrm{~g}$ for $5 \mathrm{~min}$ and resuspended with $400 \mu \mathrm{L}$ PBS, then analyzed by flow cytometer.

\section{Nude mice xenograft study}

This study was performed in compliance with the guidelines of the Ethics Committee of Institutional Animal Care and Use in Central South University. The BALB/C male nude mice were obtained from Hunan SLAC Co., Ltd. The mice were housed in a specific pathogen-free facility at Department of Laboratory, Central South University. The ATG4C stable knockdown U87-MG cells were harvested and resuspended in PBS containing Matrigel matrix (BD, USA) at a density of $1 \times 10^{8}$ cells $/ \mathrm{ml}$. Then mice were injected subcutaneously with $100 \mu \mathrm{L}$ of cells suspension $\left(1 \times 10^{7}\right.$ cells/mouse). Tumor volume and mice weight were measured after implanted for indicated time. Tumor volume $\left(\mathrm{mm}^{3}\right)=\left(\mathrm{L} \times \mathrm{W}^{2}\right) / 2$, where $\mathrm{L}$ and $\mathrm{W}$ $(\mathrm{L}>\mathrm{W})$ are the tumor's length and width. At the end point, tumor tissues were weighted and fixed in paraffin for further analysis.

\section{Immunohistochemistry (IHC)}

IHC was performed to determine the expression level of Ki67, LC3 and ATG4C in tumor tissue implanted in mice. Briefly, the formalin-fixed, paraffin-embedded samples were cut into $4 \mu \mathrm{m}$ slices. Then, tissues sections were baked, dewaxed, hydrated and blocked. Afterwards, the sections were incubated with primary antibodies against Ki-67, LC3B and ATG4C. The following day, sections were incubated with secondary antibody at room temperature. After visualizing, sections were photographed using microscope.

\section{Statistical analysis}

All statistical analysis was performed using SPSS software (version 16.0). Data were presented as the mean \pm standard deviation. Statistical analysis between two groups was performed using $t$-test. One-way ANOVA with Tamhane post-hoc was used for comparisons of different groups. Comparisons of survival rate were analyzed using Kaplan-Meier method and log-rank test. Multivariate Cox proportional hazard models were used to analyze the effect of clinical variables on patients' overall survival. $P$-value of $<0.05$ was considered as statistically significant in this study.

\section{Results \\ Higher ATG4C mRNA expression predicted poor prognosis for glioma patients}

In order to investigate the role of autophagy-related genes (ATGs) in prognosis of glioma patients, we developed an analysis flowchart (Additional file 1: Figure S1). The baseline clinical characteristics of glioma patients were shown in Table 1. We observed that the mRNA expression of 13 ATGs (ATG3, ATG4A, ATG4C, ATG5, ATG7, ATG9B, ATG10, ATG12, ATG16L1, ATG2A, ATG2B, ATG9A and $A T G 16 L 2)$ were closely associated with the OS of glioma patients (Fig. 1a and Additional file 2: Figure S2). To rule out the potential influence of WHO grade, MGMT promoter methylation, $I D H$ mutation and other clinical variables on prognosis of patients, Cox proportional hazards regression was further performed. The results showed that mRNA expression of ATG3 (HR $=0.63$, 95\% CI: $0.40-0.99, p=0.05)$, ATG4C $(\mathrm{HR}=1.54,95 \%$ CI: $1.16-2.01, p=3 \times 10^{-3}$ ) and ATG5 (HR $=0.61,95 \%$ CI: $0.43-0.86, p=5 \times 10^{-3}$ ) were independent OS prognostic factors in gliomas patients (Table 2). Given the significant influence of pathological grade on patient prognosis, these findings were further validated in low-grade glioma (LGG) patients and glioblastoma patients (GBM), respectively. We observed that only ATG4C mRNA expression was significantly associated with OS in LGG patients (Fig. $1 \mathrm{~b}$ and Additional file 3: Figure S3). Moreover, the median relapse-free survival (RFS) time of LGG patients with low ATG4C mRNA expression was significantly longer than those with high expression (Fig. 1c). However, no significant association was observed between ATGs mRNA expression and OS in GBM patients (Additional file 3: Figure S3). 

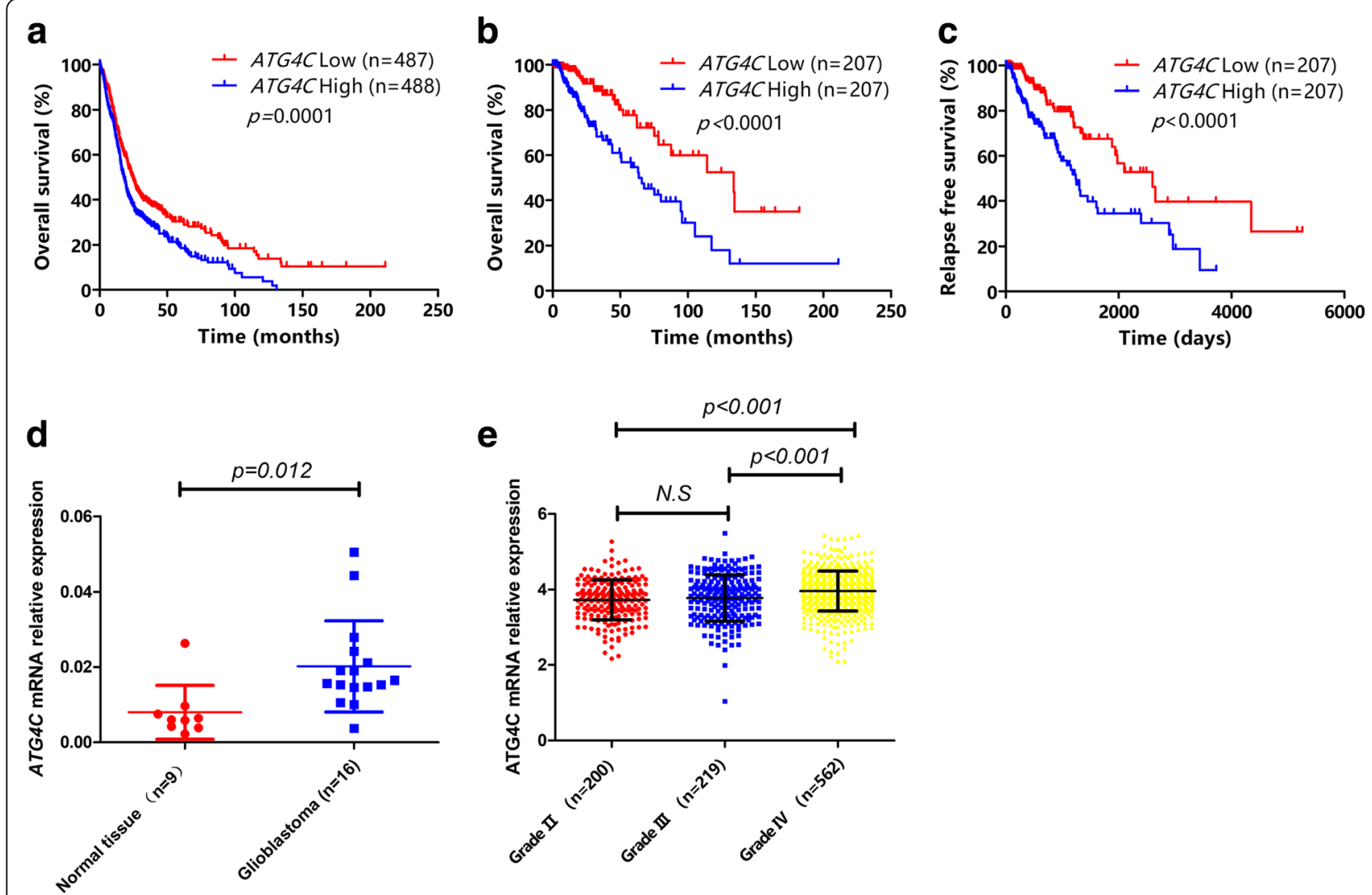

Fig. 1 Kaplan-Meier survival analysis of glioma patients based on ATG4C mRNA expression levels. a Comparison of overall survival (OS) profiles between patients with ATG4C high and low expression levels in 975 glioma patients. b Comparison of overall survival (OS) profiles between patients with ATG4C high and low expression levels in 414 LGG patients. c Comparison of relapse free survival (RFS) time between patients with ATG4C high and low expression levels in 414 LGG patients. $\mathbf{d}$ Comparison of ATG4C mRNA expression between 16 glioblastoma tissues and 9 normal brain tissues. e Comparison of the mRNA expression of ATG4C in patients with different pathological grades of gliomas

\section{mRNA expression of ATG4C was increased with} pathological grades in glioma patients

To make clear whether ATG4C was differentially expressed between glioblastoma and normal brain tissues, mRNA levels of $A T G 4 C$ was detected in 16 glioblastoma and 9 normal brain tissues. As compared with normal brain tissues, the expression of $A T G 4 C$ mRNA was significantly higher in glioblastoma tissues (Fig. 1d). We then compared the expression of $A T G 4 C$ mRNA in different grades of gliomas using TCGA database. As shown in Fig. 1e, ATG4C mRNA expression was significantly increased with the increase in glioma grade. When the patients were divided into two groups according to $A T G 4 C$ mRNA expression levels, we observed that patients with higher $A T G 4 C$ mRNA expression were more likely to develop advanced grades glioma (Table 3 ).

\section{Knockdown of ATG4C suppressed glioma cells proliferation}

The above results indicated that ATG4C mRNA expression could predict the prognosis of glioma patients, implying that $A T G 4 C$ might be involved in glioma progression and/or therapeutic response. The MTS assay and colony formation were performed to evaluate the role of ATG4C on glioma proliferation. The interference efficiency of siRNAs was validated at both mRNA and protein levels (Fig. 2a and b). Compared with control group, knockdown of ATG4C by si-RNA transfection significantly suppressed the proliferation of glioma cells indicated by proliferation curves (Fig. 2c). Results from colony-formation assay also showed that knockdown of ATG4C by si-RNA transfection reduced the number of colonies remarkably (Fig. 2d).

\section{ATG4C ablation interfered with cell cycle and the expression of cell cycle related proteins in glioma cells} The impaired proliferation of glioma cell by si-ATG4C might be a result, at least in part, from unorganized cell cycle. For this reason, we analyzed the cell cycle distribution of glioma cells after ATG4C silencing. Both U87MG and T98G cells transfected with ATG4C siRNA were accumulated in G1 phase (Fig. 3a and b). Meanwhile, knockdown of ATG4C increased the protein expression of p21 and p53 while decreased the expression of Cyclin E (Fig. 3c). 
Table 2 Cox proportional hazards regression analysis of factors associated with overall survival of glioma patients

\begin{tabular}{|c|c|c|c|c|}
\hline \multirow[t]{2}{*}{ Variable } & \multicolumn{2}{|l|}{ Univariate analysis } & \multicolumn{2}{|c|}{ Multivariate analysis } \\
\hline & HR $(95 \% \mathrm{Cl})$ & $p$ value & $\mathrm{HR}(95 \% \mathrm{Cl})$ & $p$ value \\
\hline$\overline{M G M T}$ & $0.37(0.30-0.46)$ & $6.81 \times 10^{-19}$ & $0.98(0.75-1.28)$ & 0.88 \\
\hline $\begin{array}{l}\text { IDH mutation } \\
\text { vs wild }\end{array}$ & $0.13(0.10-0.17)$ & $6.05 \times 10^{-51}$ & $0.40(0.26-0.63$ & $6.40 \times 10^{-5}$ \\
\hline Grade III vs Grade II & $3.20(1.93-5.29)$ & $5.86 \times 10^{-6}$ & $2.44(1.44-4.12)$ & $9.34 \times 10^{-4}$ \\
\hline Grade IV vs Grade II & $14.28(9.14-22.32)$ & $1.88 \times 10^{-31}$ & $5.02(2.70-9.36)$ & $3.71 \times 10^{-6}$ \\
\hline Age & $1.06(1.05-1.06)$ & $7.91 \times 10^{-58}$ & $1.05(1.03-1.06)$ & $3.85 \times 10^{-15}$ \\
\hline Gender & $1.13(0.94-1.35)$ & 0.19 & $1.51(1.17-1.93)$ & 0.014 \\
\hline ATG2A mRNA & $0.41(0.35-0.48)$ & $2.95 \times 10^{-30}$ & $1.17(0.79-1.73)$ & 0.43 \\
\hline ATG2B mRNA & $0.47(0.40-0.54)$ & $4.50 \times 10^{-24}$ & $0.98(0.75-1.27)$ & 0.86 \\
\hline ATG3 mRNA & $1.42(1.10-1.84)$ & 0.008 & $0.63(0.40-0.99)$ & 0.05 \\
\hline ATG4A mRNA & $2.37(2.02-2.79)$ & $1.04 \times 10^{-25}$ & $0.90(0.64-1.28)$ & 0.56 \\
\hline ATG4C mRNA & $1.48(1.27-1.73)$ & $9.91 \times 10^{-7}$ & $1.54(1.16-2.01)$ & $3 \times 10^{-3}$ \\
\hline ATG5 mRNA & $1.74(1.43-2.13)$ & $4.32 \times 10^{-8}$ & $0.61(0.43-0.86)$ & $5 \times 10^{-3}$ \\
\hline ATG7 mRNA & $2.32(1.89-2.86)$ & $1.66 \times 10^{-15}$ & $1.36(0.94-1.98)$ & 0.1 \\
\hline ATG9A mRNA & $0.42(0.34-0.51)$ & $7.05 \times 10^{-17}$ & $0.74(0.49-1.13)$ & 0.16 \\
\hline ATG9B mRNA & $1.44(1.33-1.57)$ & $1.57 \times 10^{-18}$ & $0.97(0.88-1.07)$ & 0.52 \\
\hline ATG10 mRNA & $2.18(1.86-2.55)$ & $1.08 \times 10^{-21}$ & $1.11(0.82-1.41)$ & 0.50 \\
\hline ATG12 mRNA & $2.05(1.62-2.61)$ & $4.59 \times 10^{-9}$ & $0.998(0.66-1.52)$ & 0.99 \\
\hline ATG16L1 mRNA & $3.17(2.53-3.97)$ & $8.53 \times 10^{-24}$ & $1.01(0.77-1.09)$ & 0.96 \\
\hline ATG16L2 mRNA & $0.78(0.70-0.88)$ & $7.22 \times 10^{-5}$ & $0.92(0.77-1.09)$ & 0.34 \\
\hline
\end{tabular}

Table 3 Comparison of distribution of clinical factors between glioma patients with high and low ATG4C mRNA expression

\begin{tabular}{llll}
\hline Clinical & NO. of patients & & $p$ value \\
\cline { 2 - 3 } characteristic & $\begin{array}{l}\text { ATG4C low } \\
\text { expression }\end{array}$ & $\begin{array}{l}\text { ATG4C high } \\
\text { expression }\end{array}$ & \\
\hline NO. of cases & 487 & 488 & \\
Age (years) & & & \\
$\quad \geq 55$ & $297(60.99 \%)$ & $249(51.02 \%)$ & 0.002 \\
$<55$ & $190(39.01 \%)$ & $239(48.98 \%)$ & \\
Gender & & & 0.348 \\
Male & $279(57.29 \%)$ & $294(60.25 \%)$ & \\
Female & $208(42.71 \%)$ & $194(39.75 \%)$ & \\
WHO grade & & & \\
II & $121(24.85 \%)$ & $77(15.78 \%)$ & \\
III & $120(24.64 \%)$ & $96(19.67 \%)$ & \\
IV & $246(50.51 \%)$ & $315(64.55 \%)$ & \\
IDH status & & & \\
Wild & $185(37.99 \%)$ & $130(26.64 \%)$ & 0.0000 \\
Mutant & $242(49.69 \%)$ & $298(61.07 \%)$ & \\
Undefined & $60(12.32 \%)$ & $60(12.30 \%)$ & \\
MGMT status & & & \\
Unmethylated & $110(22.59 \%)$ & $224(45.90 \%)$ & \\
Methylated & $290(59.55 \%)$ & $170(34.84 \%)$ & \\
Undefined & $87(17.86 \%)$ & $94(19.26 \%)$ & \\
\hline
\end{tabular}

ATG4C knockdown suppressed autophagic flux in glioma cells

Previous studies have shown that ATG4C was implicated in the formation of autophagsome [31, 32]. However, the role of ATG4C in autophagy in glioma cells was unclear. ATG4C stable knockdown glioma cell lines were established (Fig. 4a and b). The LC3II/ LC3-I ratio and expression of LC3-II and P62 are established indicators of autophagy. Intriguingly, we found that both of LC3-II and P62 protein levels were obviously increased in cells treated with si-ATG4C (Fig. 4c). In order to further confirm the role of ATG4C in autophagy, an autophagic flux assay was performed in ATG4C stable knockdown cells. Autophagic flux can be evaluated by LC3-II protein levels in the presence or absence of inhibitors of lysosomal degradation such as Bafilomycin A1 (BafA1). Our results showed that, in the presence of BafA1, knockdown of ATG4C reduced the protein expression of LC3-II remarkably, which suggested impaired autophagic flux (Fig. 4d and e). The analysis of transmission electron microscope (TEM) was performed to observe the influence of ATG4C on the formation of autophagy vacuoles in T98G cells. As shown in Fig. 4f, autophagic vacuoles was increased in T98G cells by BafA1 treatment. And in the presence of BafA1, knockdown of ATG4C reduced autophagic vacuoles. 
a

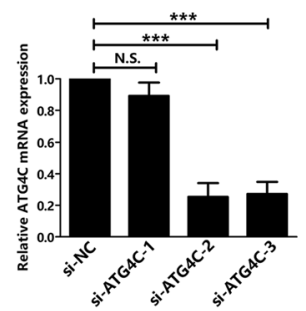

U87-MG

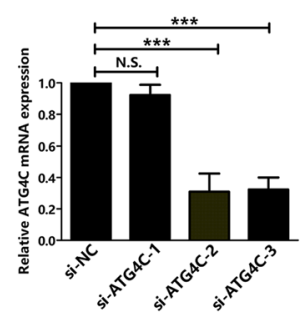

T98G b

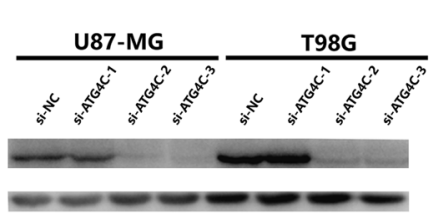

C

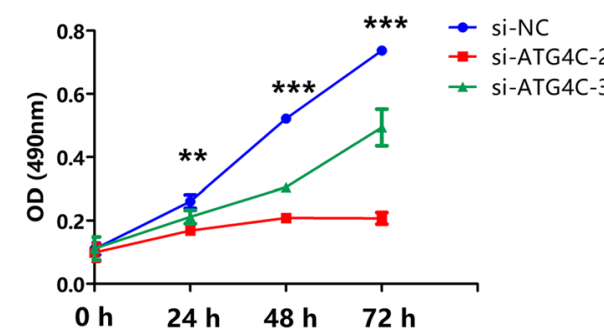

d

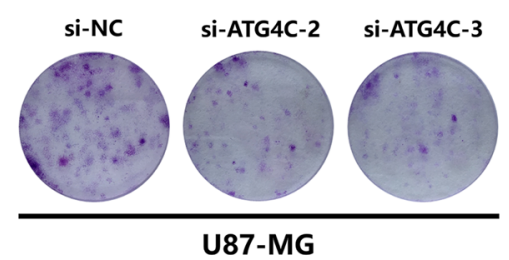

si-NC

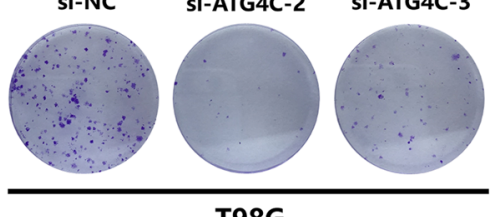

T98G
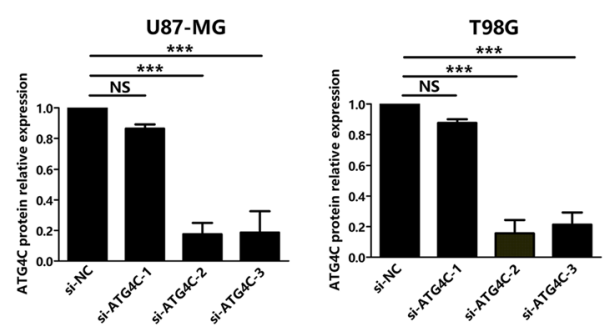

T98G
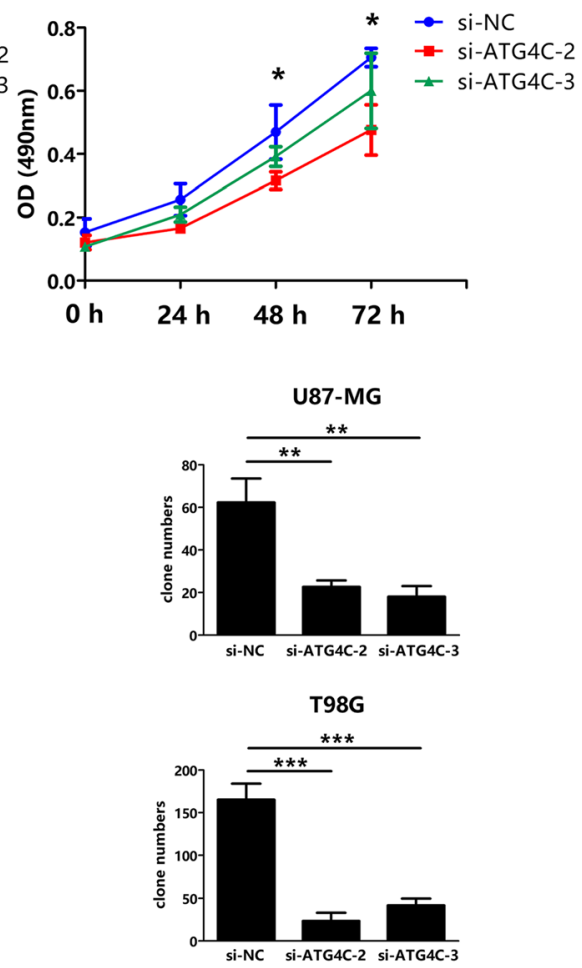

Fig. 2 Knockdown of ATG4C inhibited the proliferation of glioma cells. a-b ATG4C siRNAs interference efficiency was tested at both mRNA and protein levels. c ATG4C knockdown by si-ATG4C transfection suppressed the proliferation of glioma cells in a time-dependent manner. $\mathbf{d}$ ATG4C knockdown by si-ATG4C transfection impaired clone formation ability of glioma cells. Left panel: representative crystal violet staining images; right panel: quantitative analysis of colony numbers. ${ }^{*} p<0.05,{ }^{* *} p<0.01,{ }^{* * *} p<0.001$, NS: not significant

ATG4C depletion triggered apoptosis by increasing ROS Beside immortal proliferation, decreased apoptosis is another important malignant biological behavior of gliomas. The effect of ATG4C on apoptosis was investigated in
T98G using Annexin V-FITC/PI and Hoechst 33342 staining. As shown in Fig. 5a and b, knockdown of ATG4C significantly promoted apoptosis in T98G cells. And ATG4C depletion-induced apoptosis was further enhanced 


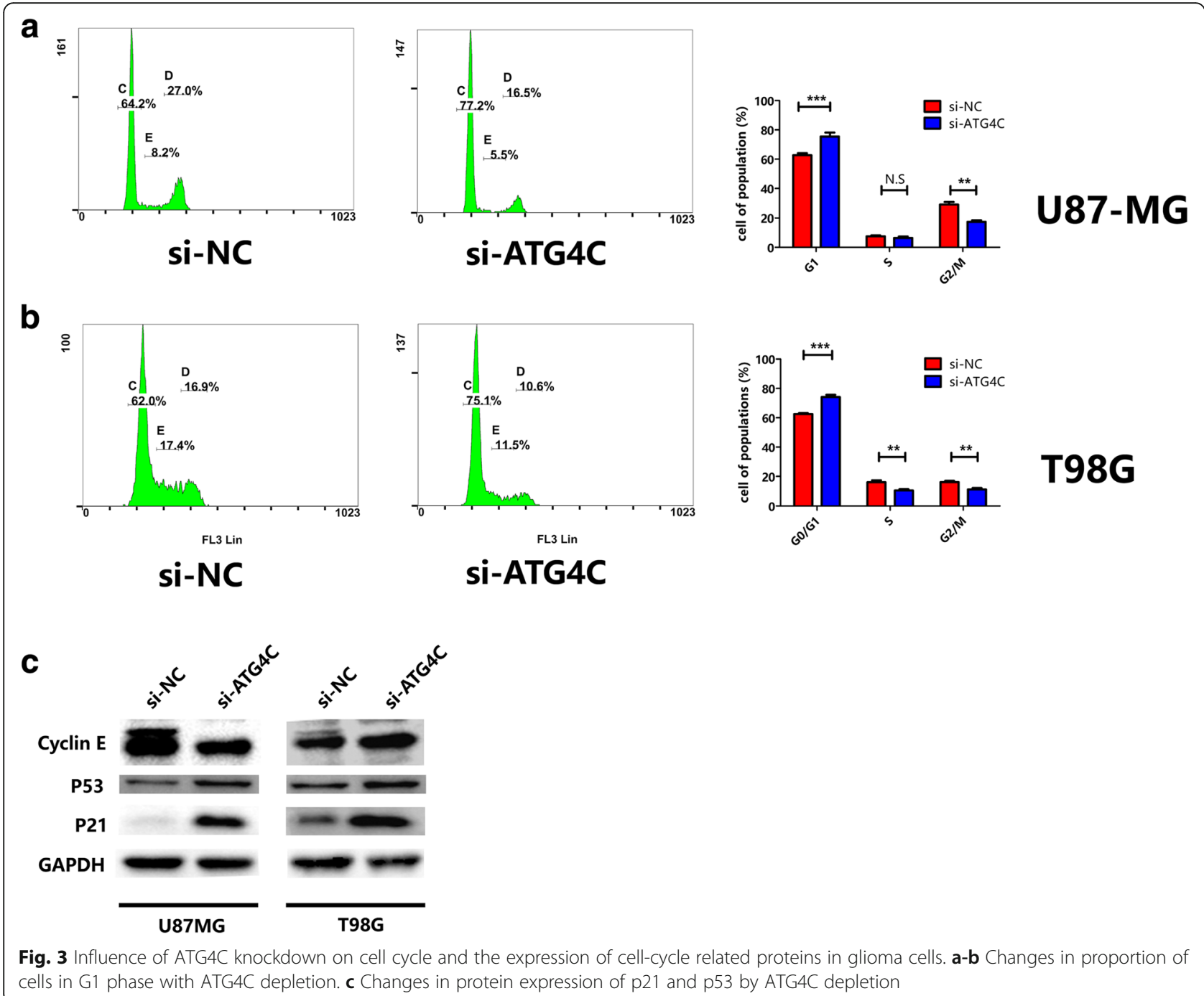

by starvation, a known factor for autophagy stimulation. Western blot analysis showed that ATG4C ablation remarkably increased the expression of pro-apoptosis proteins BAX and cleaved-PARP, while reduced the expression of the anti-apoptosis protein Bcl-2 (Fig. 5c). Consistently, ATG4C ablation significantly increased the activity of caspase-3/6/9 (Fig. 5d). Autophagy deficiency is reported to lead to an increase in ROS levels and then trigger apoptosis. For this reason, we further investigated the influence of ATG4C ablation on ROS production. As shown in Fig. 5e, ATG4C ablation increased the level of ROS remarkably in a time-dependent manner in T98G cells.

\section{ATG4C depletion increased the sensitivity of glioma cells to $\mathrm{TMZ}$}

Previous studies have shown that TMZ-induced autophagy sustained the survival of tumor cells, which contributed to treatment resistance. Blocking autophagy with inhibitors can significantly increase TMZ cytotoxicity in glioma cells. However, it is unknown whether ATG4C is involved in the TMZ-activated autophagy. To validate the effect of TMZ in activating autophagy in glioma cells, U87-MG and T98G cells were treated with series concentrations of $\operatorname{TMZ}(12.5,25$, and $50 \mu \mathrm{M}$ for U87MG cells, and 200, 400, 800, $1600 \mu \mathrm{M}$ for T98G cells). Western blot analysis showed that TMZ increased the LC3-II/LC3-I ratio and LC3-II protein levels in a concentration-dependent manner in both cells (Fig. 6a). TMZ treatment also decreased the protein expression of P62 significantly (Fig. 6a). The autophagy activating effect of TMZ in glioma cells was further confirmed by an increase in RFP-GFP-LC3 puncta (Fig. 6b). Additionally, RT-qPCR analysis showed a significant increase in ATG4C mRNA levels with increasing TMZ concentrations (Fig. 6c). Moreover, we observed that ATG4C ablation blocked the accumulation of LC3II in the presence of BafA1 in the glioma cells treated with TMZ (Fig. 6d). Consistently, ATG4C depletion significantly 

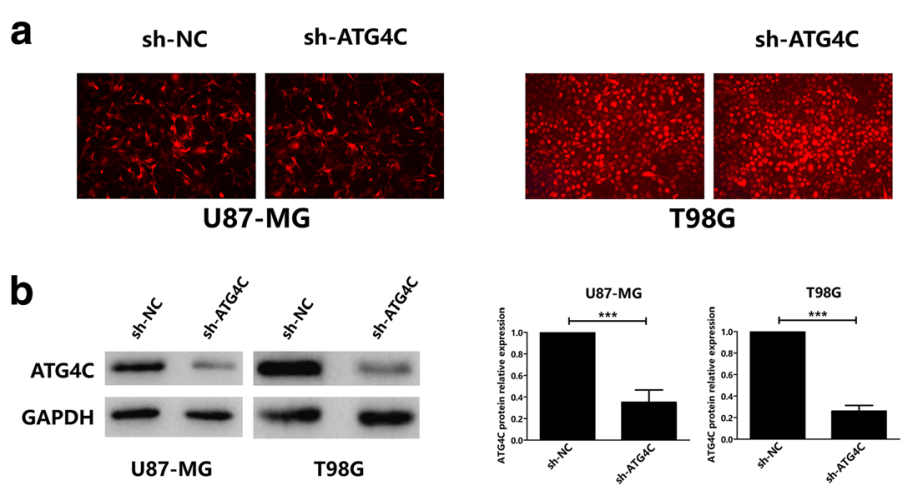

C
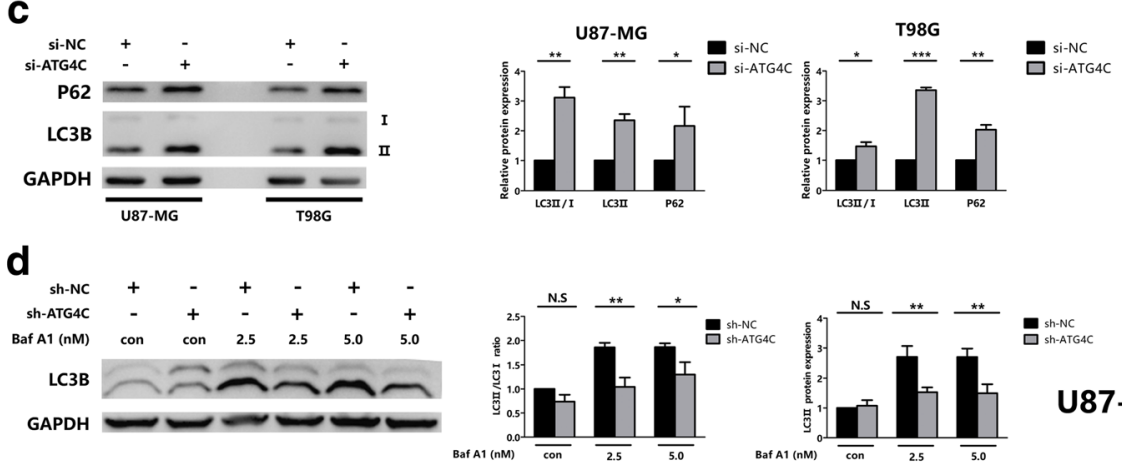

U87-MG
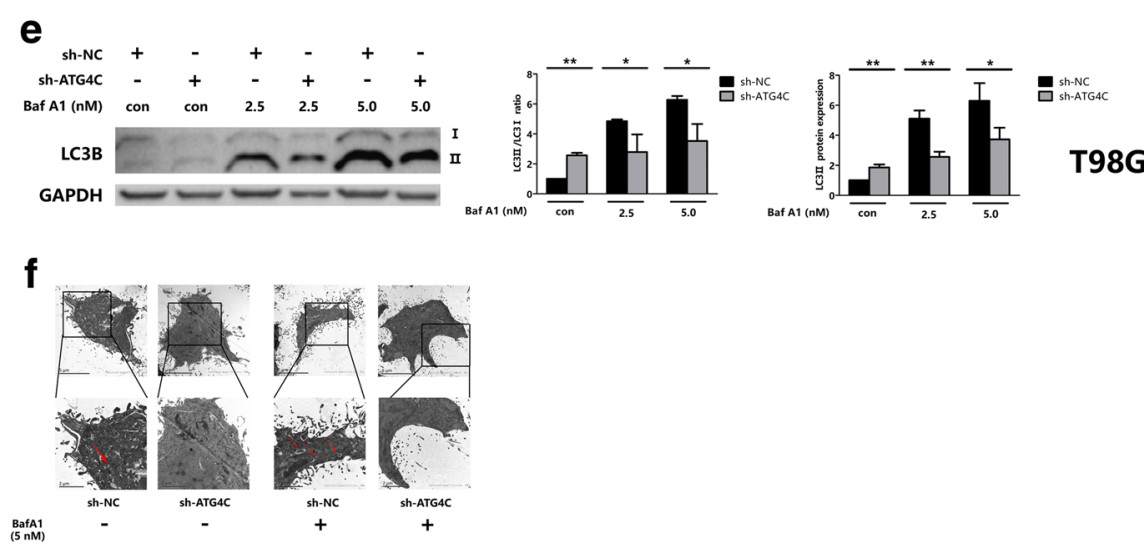

Fig. 4 Knockdown of ATG4C suppressed autophagy and autophagic flux. a, b ATG4C stable knockdown glioma cells were established by lentivirus infection, and the interference efficiency was detected by Western blot analysis. c Protein expression of LC3-II and P62 in glioma cells transfected with si-ATG4C. d, e Knockdown of ATG4C on the expression of LC3-II in the presence of BafA1. $\mathbf{f}$ Transmission electron microscopy observation of cellular ultrastructure tin T98G cells by ATG4C depletion. Arrows indicate autophagic vacuoles. ${ }^{*} p<0.05,{ }^{* *} p<0.01,{ }^{* *} p<0.001$, NS: not significant

decreased the increase of GFP-LC3 dots induced by TMZ (Fig. 6e). All these results suggested that ATG4C was involved in TMZ-induced autophagy. As shown in Fig. 6f, ATG4C ablation also decreased the $\mathrm{IC}_{50}$ of TMZ in both U87MG and T98G cells obviously (Fig. 6f).

\section{ATG4C knockdown inhibited the growth of xenograft tumor}

In order to investigate the effects of ATG4C on glioma growth in vivo, a xenograft nude mouse model was established. ATG4C stable knockdown U87-MG cells were implanted in nude mice and showed significantly slower growth than those in control group (Fig. $7 \mathrm{a}$ and $\mathrm{b}$ ). Additionally, the tumors from mice injected with ATG4C depleted U87-MG cells was significantly smaller than those in control group (Fig. 7c). Moreover, ATG4C knockdown also remarkably impaired the proliferation of primary glioblastoma cells (Additionaly file 4: Figure S4). Immunohistochemical (IHC) staining was performed to detect the expression of Ki67, LC3 and ATG4C in 


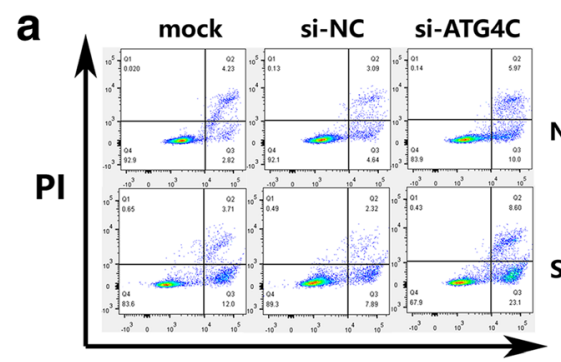

Annevin-V

b
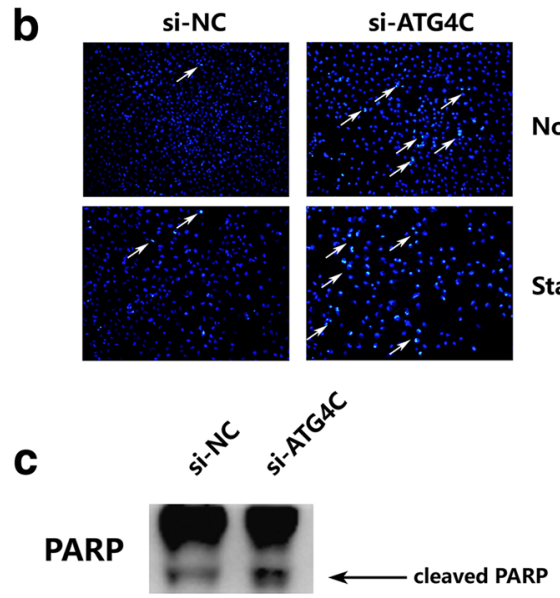

Bcl-2

BAX

GAPDH
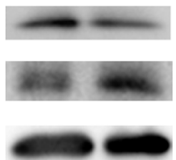
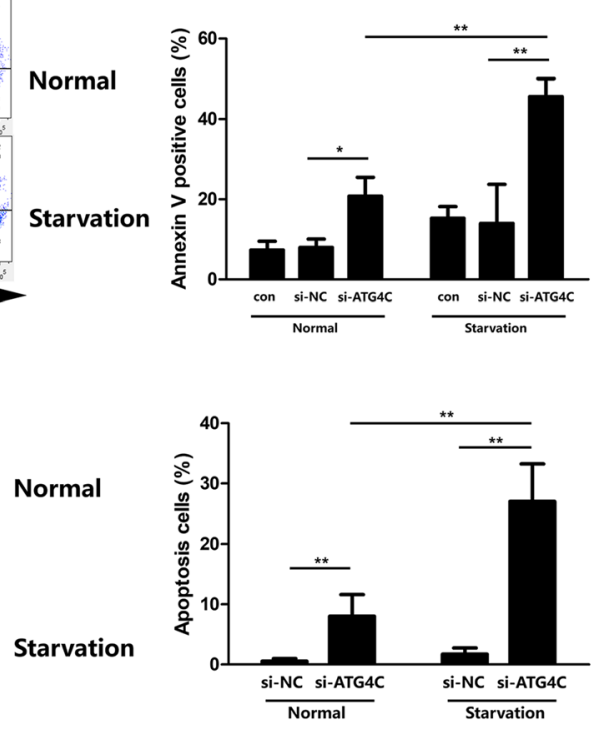

d
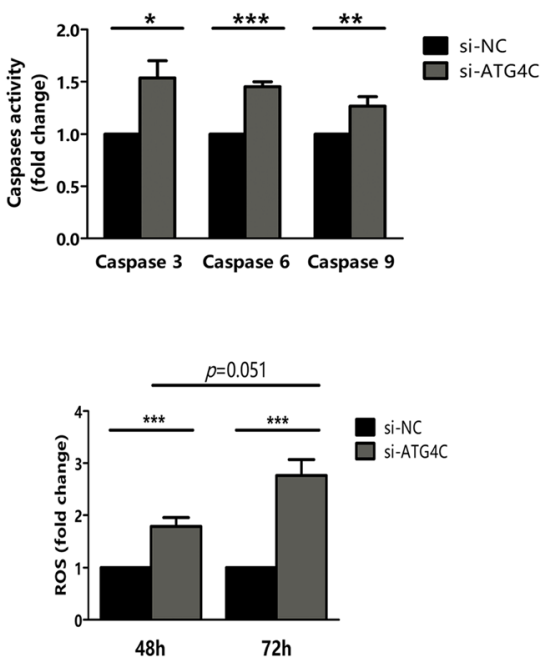

Fig. 5 Knockdown of ATG4C promoted apoptosis and increased ROS accumulation in T98G cells. a-b The apoptosis in T98G cell transfected with si-ATG4C was detected by Annevin-V and Hoechst 33342 staining, respectively. c Changes in protein levels of cleaved-PARP, BAX and Bcl-2 expression in T98G cells transfected with ATG4C siRNAs. $\mathbf{d}$ Changes in Caspase-3/6/9 activity in T98G cells transfected with ATG4C siRNAs. e Changes in ROS levels in T98G cells transfected with ATG4C siRNAs. ${ }^{*} p<0.05,{ }^{* *} p<0.01,{ }^{* * *} p<0.001$, NS: not significant

the xenograft. As shown in Fig. 7d, the expression of Ki67, LC3 and ATG4C were decreased significantly in tumor tissues from sh-ATG4C group.

\section{Discussion}

In this study, we identified that the mRNA level of $A T G 4 C$ was associated with worse prognosis in glioma patients. ATG4C levels was evidently elevated with the rising of glioma grade. Knockdown of ATG4C markedly suppressed the growth of glioma and promoted apoptosis in glioma cells, which was accompanied by increased ROS production. Additionally, cytotoxicity of TMZ was increased while the TMZ-induced autophagy was reduced in ATG4C depleted glioma cells.

More and more molecular biomarkers are identified and applied to improve the diagnosis and treatment of gliomas. However, the prognosis of the disease still remains gloomy [3, 33-37]. And also, it is of desperate need to find promising therapeutic targets for glioma. In this study, we observed that ATG4C was differently 

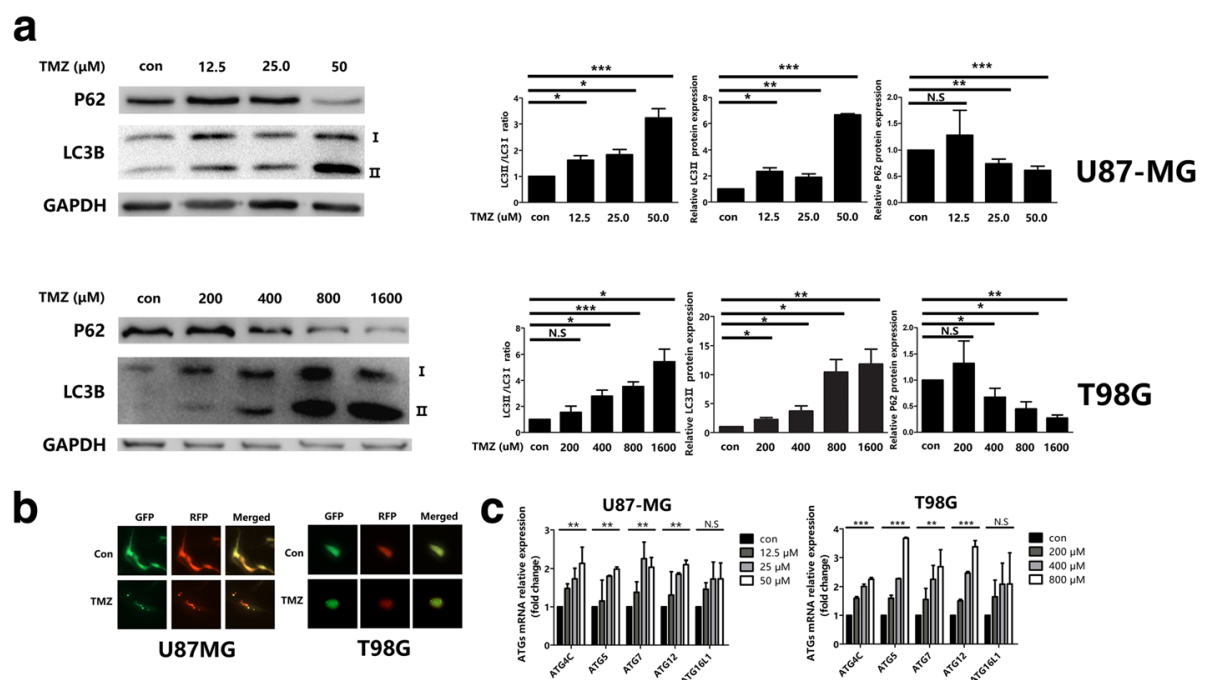

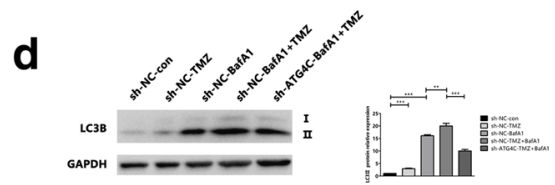

U87-MG
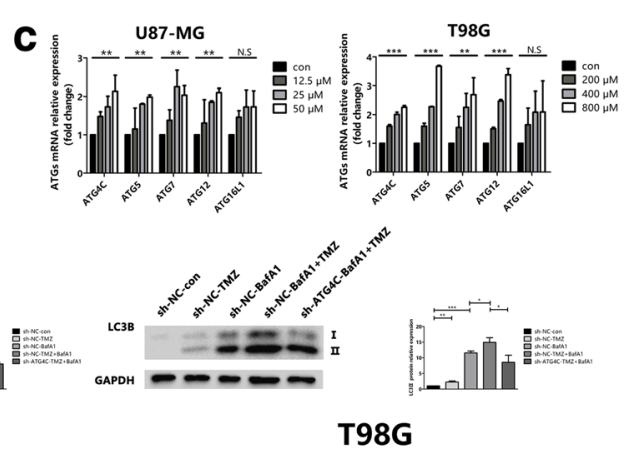

e

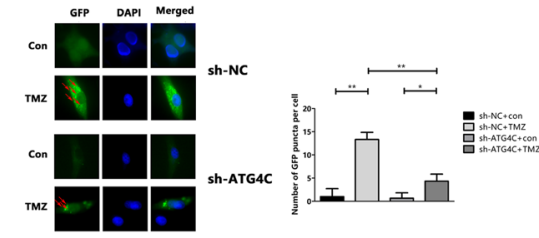

U87-MG

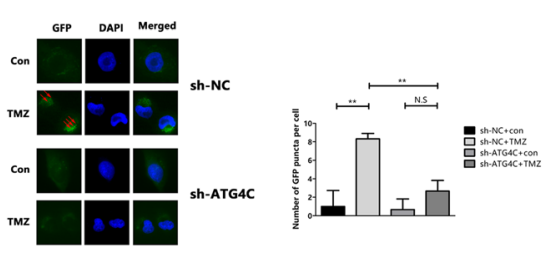

T98G
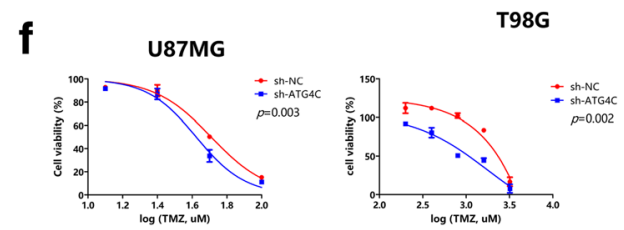

Fig. 6 Knockdown of ATG4C enhanced TMZ cytotoxicity in glioma cells by suppressing autophagy. a Both LC3-II/LC3-I ratio and LC3-II expression were increased and P62 expression was decreased in glioma cells treated with TMZ. b The number of yellow puncta was elevated in glioma cells treated with TMZ. c The expression of ATGs mRNA were increased in glioma cells treated with TMZ. d Knockdown of ATG4C by sh-ATG4C decreased the expression of LC3-II in the presence of BafA1 in glioma cells treated with TMZ. e Knockdown of ATG4C by sh-ATG4C decreased the number of green puncta (red arrows) in glioma cells treated with TMZ. $\mathbf{f}$ Knockdown of ATG4C by sh-ATG4C increased TMZ cytotoxicity in glioma cells. ${ }^{*} p<0.05,{ }^{* *} p<0.01,{ }^{* * *} p<0.001$, NS: not significant

expressed between normal brain and glioblastoma tissues, and its expression was increased with the grade of glioma. And also, we observed that ATG4C level was an independent predictor for OS and RFS in LGG patients (Additional files 6 and 7: Tables S2 and S3). To make clear whether ATG4C acts through affecting cell growth in gliomas, we observed its role in proliferation of gliomas cells. We demonstrated that knockdown ATG4C remarkably suppressed the proliferation of glioma cell lines by inducing cell cycle arrest at G1 phase. It is obvious that cell cycle transitions in eukaryotic cells are regulated by cyclin-dependent kinases (CDKs)-cyclin complexes [38]. The CDK inhibitor P21 is an important regulator of cell growth in mammalian cells [39] as well as a universal cell-cycle inhibition controlled by P53 $[40,41]$. In our current works, we observed that knockdown ATG4C induced a decrease in Cyclin E and an increase in P21 and P53 expression, which indicate obvious cell cycle arrest caused by ATG4C ablation. Additionally, we observed that knockdown ATG4C could restrain the 


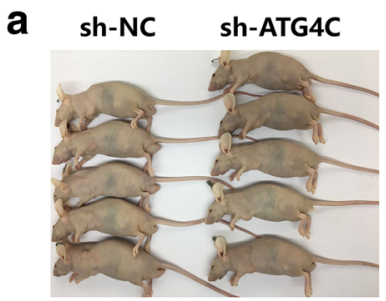

b

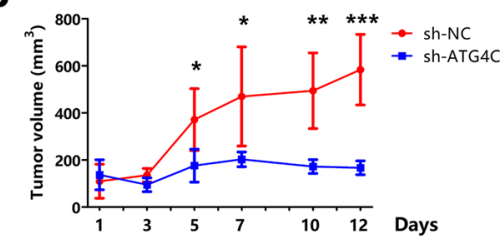

C

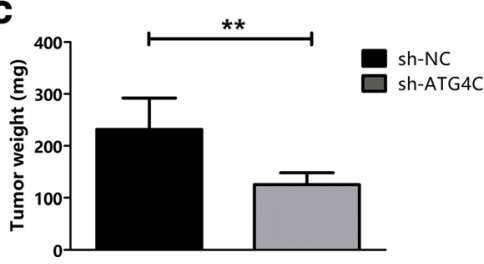

e

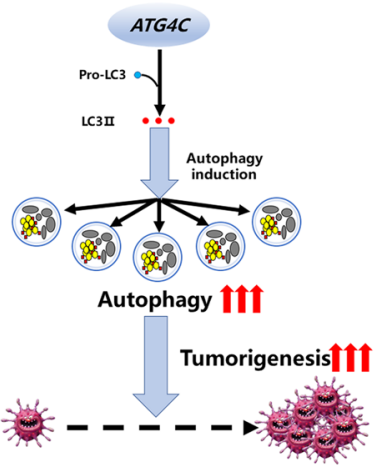

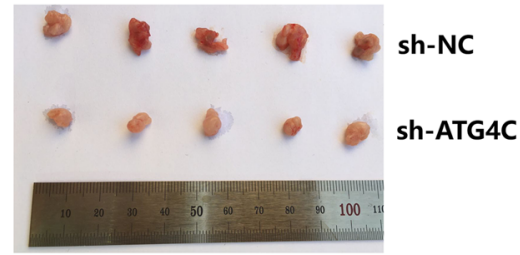

d

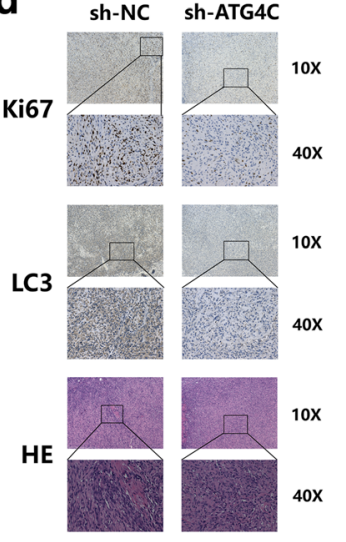

Fig. 7 Knockdown of ATG4C by sh-ATG4C suppressed xenograft tumor and the graphic abstract. $\mathbf{a}$-b The growth of glioma was restricted in nude mice by ATG4C knockdown. c Knockdown of ATG4C decreased the xenograft weights. $\mathbf{d}$ Depletion of ATG4C reduced the expression of Ki67, LC3 and ATG4C protein in xenograft. e Graph depicts the role of ATG4C in glioma progression and TMZ sensitivity

proliferation of primarily cultured glioblastoma cells from patients (Additional file 3: Figure S3). A large body of evidence suggests that inhibition of the activity of other ATG4 family members, including ATG4A, ATG4B and ATG4D, could suppress tumor progression and enhance chemosensitivity or the efficacy of radiotherapy [42-49]. These findings consistently implied that the ATG4 family played an important role in tumorigenesis and cancer therapy. Development of ATG4C specific inhibitors may bring new promising strategy for glioma treatment.

The role of ATG4C in autophagy in glioma cells is not clear. Previous researches suggested that the miR-376 mediated ATG4C silencing could suppress autophagy in breast cancer cells and hepatocarcinoma cells [31, 32]. Recently, there was data implied that ATG4C had a limited role in autophagy [50]. In the current work, we observed that LC3-II expression was significantly reduced in the presence of BafA1 in sh-ATG4C cells, indicating impaired autophagic flux. Results from transmission electron microscope (TEM) analysis also observed a decrease in autophagic vacuoles by ATG4C silencing, in the presence of BafA1. However, we observed concomitantly increased protein expression of LC3-II and P62 in glioma cells transfected with siATG4C. It seems to be intriguing. According to the functions of ATG4 family members in LC3 processing, ATG4C is putative to cleavage of pro-LC3 and delipidation of LC 3 II from the membrane of the autophagsome through the cysteine peptidase activity [28, 31, 32]. Of course, the possible role of ATG4C in LC3-II 
degradation at late stage of autophagy could not be excluded in our study.

Autophagy is essential for the removal of damaged mitochondria, which are primary sources of intracellular ROS [16]. Autophagy deficiency can lead to an increase in ROS, which contribute to the DNA damage, genomic instability and then trigger apoptosis [51-54]. In our study, we found that ROS levels were increased remarkably in T98G cells transfected with si-ATG4C for $48 \mathrm{~h}$, and a significant increase in apoptosis was observed followed by si-ATG4C transfection for $72 \mathrm{~h}$. These findings implied that ATG4C ablation could suppress autophagy in glioma cells and then trigger apoptosis by increasing ROS levels. However, ROS scavengers should be used to test whether ATG4C depletion-induced apoptosis was ROS-dependent. Moreover, ectopic xenograft nude mice model was used to establish the influence of ATG4C on glioma growth in vivo. Consistent with the in vivo findings, knockdown ATG4C restrained the proliferation of glioma with significantly decreased tumor volumes and weights. In tumor tissues of mice xenograft, the expression of both Ki67 and LC3 proteins were decreased in the sh-ATG4C group. These results indicated that ATG4C ablation may impaired the proliferation of glioma through suppressing autophagy in vivo.

TMZ is the first-line chemotherapeutic drug for glioma. The drug undergoes spontaneous hydrolysis to 5(3-methyltriazen-1-yl) imidazole-4-carboxamide (MITC) and then forms $\mathrm{O}^{6}$-methylguanine $\left(\mathrm{O}^{6}-\mathrm{MeG}\right)$ in neutral pH. $\mathrm{O}^{6}-\mathrm{MeG}$ lead to DNA mispairs during DNA replication, and that results in DNA double strand breaks through futile cycles of mismatch repair system $[55,56]$. In the treatment of glioma, cytotoxicity chemotherapeutics drugs including TMZ can induce autophagy, which may promote the development of treatment resistance $[23-25,57]$. In our study, we observed for the first time that ATG4C is involved in TMZ-induced autophagy, and depletion of ATG4C significantly increased the sensitivity of U87-MG and T98G cells to TMZ, which are thought to be TMZ sensitivity and resistance cells, respectively [58]. Selective and specific cytotoxicity to tumor cells is expected during glioma chemotherapy, which can increase the anti-tumor activity of TMZ with less toxic effects. However, these findings need to be further validated in vivo. Given that ATG4C expression was increased in tumor tissues of glioma, a therapy targeting ATG4C may provide a promising strategy for gliomas treatment.

\section{Conclusion}

Taken together, our results suggested that increased ATG4C expression was associated with worse prognosis in glioma patients. Knockdown of ATG4C suppressed glioma progression by inducing cell cycle arrest and promoting apoptosis of glioma cells possibly through increasing ROS production. Additionally, ATG4C ablation could promote TMZ cytotoxicity to glioma cells by inhibiting autophagy. Therefore, ATG4C might be potential target for the treatment of gliomas.

\section{Additional files}

\begin{abstract}
Additional file 1: Figure S1. Flow chart of procedures for screening of ATGs associated with outcomes of glioma patients. (TIF $90 \mathrm{~kb}$ )
\end{abstract}

Additional file 2: Figure S2. Survival analysis of glioma patients based on expression of ATGs. (a-m) Kaplan-Meier analysis for OS in gliomas patients. (TIF $2897 \mathrm{~kb}$ )

Additional file 3: Figure S3. Survival analysis of LGG based on expression of ATGs. (TIF $2249 \mathrm{~kb}$ )

Additional file 4: Figure S4. Knockdown of ATG4C suppressed cell growth in glioblastoma primary cells. a The expression of GFAP in glioblastoma primary cells. b ATG4C knockdown suppressed the proliferation of primarily cultured glioblastoma cells. (TIF $952 \mathrm{~kb}$ )

Additional file 5: Table S1. Sequences of primers used for RT-qPCR (DOCX $14 \mathrm{~kb}$ )

Additional file 6: Table S2. Cox proportional hazards regression analysis for OS in LGG patients. (DOCX $17 \mathrm{~kb}$ )

Additional file 7: Table S3. Cox proportional hazards regression analysis for RFS in LGG patients. (DOCX $18 \mathrm{~kb}$ )

\section{Abbreviations}

ATG4C: Autophagy Related 4C Cysteine Peptidase; DMEM: Dulbecco's Modified Eagle's Medium; FBS: Fetal Bovine Serum; GBM: Glioblastoma; IHC: Immunohistochemistry; LGG: Low Grade Glioma; MITC: 5-(3methyltriazen-1-yl) imidazole-4-carboxamide; $\mathrm{O}^{6}-\mathrm{MeG}$ : ROS: $\mathrm{O}^{6}{ }_{-}$ methylguanine; Reactive Oxygen Species; OS: Overall Survival; qPCR: Quantitative polymerase chain reaction; RFS: Relapse-Fess Survival; TCGA: The Cancer Genome Atlas; TEM: Transmission electron microscope; TMZ: Temozolomide; WHO: World Health Organization

\section{Acknowledgements}

The RFP-GFP-LC3 plasmid were gift from Prof. Yan Cheng (Department of Pharmacology, School of Pharmaceutical Science, Central South University). We most cordially thank all members of the Department of Neurosurgery for assisting in samples collection of this works.

\section{Authors' contributions}

Substantial contributions to conception and design, data acquisition and manuscript drafting: ZPW; Glioma tissues collection: YHC and JYW; TCGA data mining: QC; Transmission electron microscope analysis: JY; Drafting the article or critically revising it for important intellectual content: WJZ, HL, JY and XPC; Final approval of the version to be published: JX and XPC; Agreement to be accountable for all aspects of the work in ensuring that questions related to the accuracy or integrity of the work are appropriately investigated and resolved: $\mathrm{HHZ}$ and XPC. All authors read and approved to the final manuscript.

\section{Funding}

This work was supported by National Natural Science Foundation of China (NO. 81803582, NO.81703622); China Postdoctoral Science Foundation (NO. 2018 M633002); Hunan Provincial Natural Science Foundation of China (NO.2018JJ3838); Fundamental Research Funds for the Central Universities of Central South University (NO.2018zzts902).

Availability of data and materials

All data generated or analyzed during this study are included in this published article. The TCGA data set can download from: http://www. cbioportal.org/study.do?cancer_study_id=lgggbm_tcga_pub. 


\section{Ethics approval and consent to participate}

The present study was approved by the Medical Ethics Committee of the Xiangya Hospital of Central South University (No. 201803806). In this study, all procedures were performed in accordance with the Declaration of Helsinki. The animal experiment in this study was approved by the Department of Laboratory Animals of Central South University and performed in compliance with the guidelines of the Ethics Committee of Institutional Animal Care and Use in Central South University.

\section{Consent for publication}

Not applicable.

\section{Competing interests}

The authors declare that they have no competing interests.

\section{Author details}

'Department of Clinical Pharmacology, Xiangya Hospital, Central South University, Changsha, Hunan 410008, People's Republic of China. ${ }^{2}$ Institute of Clinical Pharmacology, Central South University; Hunan Key Laboratory of Pharmacogenetics, Changsha, Hunan 410078, People's Republic of China. ${ }^{3}$ National Clinical Research Center for Geriatric Disorders, Xiangya Hospital, Central South University, Changsha, Hunan 410008, People's Republic of China. ${ }^{4}$ Medical Genetic Institute of Henan Province, Henan Provincial Key Laboratory of Genetic Diseases and Functional Genomics, Henan Provincial People's Hospital, People's Hospital of Zhengzhou University, Zhengzhou, Henan, Hunan, People's Republic of China. ${ }^{5}$ Department of Neurosurgery, Xiangya Hospital, Central South University, Changsha, Hunan 410008, People's Republic of China. ${ }^{6}$ Department of Oncology, Xiangya Hospital, Central South University, Changsha 410008, Hunan province, China. ${ }^{7}$ Department of Pharmacy, Xiangya Hospital, Central South University, Changsha, Hunan 410008, People's Republic of China.

Received: 3 January 2019 Accepted: 24 June 2019

Published online: 10 July 2019

\section{References}

1. Osuka S, Van Meir EG. Overcoming therapeutic resistance in glioblastoma: the way forward. J Clin Invest. 2017;127(2):415-26.

2. Reifenberger $\mathrm{G}$, Wirsching $\mathrm{HG}$, Knobbe-Thomsen $\mathrm{CB}$, Weller M. Advances in the molecular genetics of gliomas - implications for classification and therapy. Nat Rev Clin Oncol. 2017;14(7):434-52.

3. Louis DN, Perry A, Reifenberger G, von Deimling A, Figarella-Branger D, Cavenee WK, Ohgaki H, Wiestler OD, Kleihues P, Ellison DW. The 2016 World Health Organization classification of tumors of the central nervous system: a summary. Acta Neuropathol. 2016;131(6):803-20.

4. Zeng WJ, Yang YL, Liu ZZ, Wen ZP, Chen YH, Hu XL, Cheng Q, Xiao J, Zhao $\mathrm{J}$, Chen XP. Integrative analysis of DNA methylation and gene expression identify a three-gene signature for predicting prognosis in lower-grade gliomas. Cell Physiol Biochem. 2018;47(1):428-39.

5. Cancer Genome Atlas Research N, Brat DJ, Verhaak RG, Aldape KD, Yung WK, Salama SR, Cooper LA, Rheinbay E, Miller CR, Vitucci M, et al. Comprehensive, integrative genomic analysis of diffuse lower-grade gliomas. N Engl J Med. 2015;372(26):2481-98.

6. Ostrom QT, Gittleman H, Fulop J, Liu M, Blanda R, Kromer C, Wolinsky Y, Kruchko C, Barnholtz-Sloan JS. CBTRUS statistical report: primary brain and central nervous system tumors diagnosed in the United States in 20082012. Neuro-Oncology. 2015;17(Suppl 4):iv1-iv62.

7. Huse JT, Holland EC. Targeting brain cancer: advances in the molecular pathology of malignant glioma and medulloblastoma. Nat Rev Cancer. 2010;10(5):319-31.

8. Ricard D, Idbaih A, Ducray F, Lahutte M, Hoang-Xuan K, Delattre JY. Primary brain tumours in adults. Lancet. 2012;379(9830):1984-96.

9. Hegi ME, Diserens AC, Gorlia T, Hamou MF, de Tribolet N, Weller M, Kros JM, Hainfellner JA, Mason W, Mariani L, et al. MGMT gene silencing and benefit from temozolomide in glioblastoma. N Engl J Med. 2005;352(10):997-1003.

10. Amaravadi R, Kimmelman AC, White E. Recent insights into the function of autophagy in cancer. Genes Dev. 2016;30(17):1913-30.

11. Nanegrungsunk D, Onchan W, Chattipakorn N, Chattipakorn SC. Current evidence of temozolomide and bevacizumab in treatment of gliomas. Neurol Res. 2015;37(2):167-83.
12. Wait SD, Prabhu RS, Burri SH, Atkins TG, Asher AL. Polymeric drug delivery for the treatment of glioblastoma. Neuro-Oncology. 2015; 17(Suppl 2):ii9-ii23.

13. Stupp R, Mason WP, van den Bent MJ, Weller M, Fisher B, Taphoorn MJ, Belanger K, Brandes AA, Marosi C, Bogdahn U, et al. Radiotherapy plus concomitant and adjuvant temozolomide for glioblastoma. N Engl J Med. 2005;352(10):987-96.

14. Levine B, Kroemer G. Autophagy in the pathogenesis of disease. Cell. 2008; 132(1):27-42

15. Mizushima N, Komatsu M. Autophagy: renovation of cells and tissues. Cell. 2011;147(4):728-41.

16. Kongara S, Karantza $\mathrm{V}$. The interplay between autophagy and ROS in tumorigenesis. Front Oncol. 2012;2:171.

17. Qu X, Yu J, Bhagat G, Furuya N, Hibshoosh H, Troxel A, Rosen J, Eskelinen EL, Mizushima N, Ohsumi Y, et al. Promotion of tumorigenesis by heterozygous disruption of the beclin 1 autophagy gene. J Clin Invest. 2003; 112(12):1809-20.

18. Yue $Z$, Jin S, Yang C, Levine AJ, Heintz N. Beclin 1, an autophagy gene essential for early embryonic development, is a haploinsufficient tumor suppressor. Proc Natl Acad Sci U S A. 2003;100(25):15077-82.

19. Takahashi Y, Coppola D, Matsushita N, Cualing HD, Sun M, Sato Y, Liang C, Jung JU, Cheng JQ, Mule JJ, et al. Bif-1 interacts with Beclin 1 through UVRAG and regulates autophagy and tumorigenesis. Nat Cell Biol. 2007; 9(10):1142-51.

20. Kim J, Kundu M, Viollet B, Guan KL. AMPK and mTOR regulate autophagy through direct phosphorylation of Ulk1. Nat Cell Biol. 2011;13(2):132-41.

21. Yang S, Wang $X$, Contino G, Liesa M, Sahin E, Ying H, Bause A, Li Y, Stommel JM, Dell'antonio $G$, et al. Pancreatic cancers require autophagy for tumor growth. Genes Dev. 2011;25(7):717-29.

22. Huang T, Kim CK, Alvarez AA, Pangeni RP, Wan X, Song X, Shi T, Yang Y, Sastry N, Horbinski CM, et al. MST4 phosphorylation of ATG4B regulates Autophagic activity, Tumorigenicity, and Radioresistance in glioblastoma. Cancer Cell. 2017;32(6):840-55 e848.

23. Lee SW, Kim HK, Lee NH, Yi HY, Kim HS, Hong SH, Hong YK, Joe YA. The synergistic effect of combination temozolomide and chloroquine treatment is dependent on autophagy formation and p53 status in glioma cells. Cancer Lett. 2015;360(2):195-204.

24. Lin CJ, Lee CC, Shih YL, Lin TY, Wang SH, Lin YF, Shih CM. Resveratrol enhances the therapeutic effect of temozolomide against malignant glioma in vitro and in vivo by inhibiting autophagy. Free Radic Biol Med. 2012;52(2):377-91.

25. Zanotto-Filho A, Braganhol E, Klafke K, Figueiro F, Terra SR, Paludo FJ, Morrone M, Bristot IJ, Battastini AM, Forcelini CM, et al. Autophagy inhibition improves the efficacy of curcumin/temozolomide combination therapy in glioblastomas. Cancer Lett. 2015;358(2):220-31.

26. White $E$. The role for autophagy in cancer. J Clin Invest. 2015;125(1):42-6.

27. Rosenfeld MR, Ye X, Supko JG, Desideri S, Grossman SA, Brem S, Mikkelson T, Wang D, Chang YC, Hu J, et al. A phase I/II trial of hydroxychloroquine in conjunction with radiation therapy and concurrent and adjuvant temozolomide in patients with newly diagnosed glioblastoma multiforme. Autophagy. 2014;10(8):1359-68.

28. Zhang L, Li J, Ouyang L, Liu B, Cheng Y. Unraveling the roles of Atg4 proteases from autophagy modulation to targeted cancer therapy. Cancer Lett. 2016;373(1):19-26.

29. Li M, Hou Y, Wang J, Chen X, Shao ZM, Yin XM. Kinetics comparisons of mammalian Atg4 homologues indicate selective preferences toward diverse Atg8 substrates. J Biol Chem. 2011;286(9):7327-38.

30. Antonelli M, Strappazzon F, Arisi I, Brandi R, D'Onofrio M, Sambucci M, Manic G, Vitale I, Barila D, Stagni V. ATM kinase sustains breast cancer stemlike cells by promoting ATG4C expression and autophagy. Oncotarget. 2017; 8(13):21692-709.

31. Korkmaz G, le Sage C, Tekirdag KA, Agami R, Gozuacik D. miR-376b controls starvation and mTOR inhibition-related autophagy by targeting ATG4C and BECN1. Autophagy. 2012;8(2):165-76.

32. Korkmaz G, Tekirdag KA, Ozturk DG, Kosar A, Sezerman OU, Gozuacik D. MIR376A is a regulator of starvation-induced autophagy. PLoS One. 2013;8(12):e82556.

33. Xu J, Fang J, Cheng Z, Fan L, Hu W, Zhou F, Shen H. Overexpression of the Kininogen-1 inhibits proliferation and induces apoptosis of glioma cells. J Exp Clin Cancer Res. 2018;37(1):180.

34. Zhu T, Xie P, Gao YF, Huang MS, Li X, Zhang W, Zhou HH, Liu ZQ. Nucleolar and spindle-associated protein 1 is a tumor grade correlated prognosis marker for glioma patients. CNS Neurosci Ther. 2018;24(3):178-86. 
35. Huang CH, Li XJ, Zhou YZ, Luo Y, Li C, Yuan XR. Expression and clinical significance of EGFL7 in malignant glioma. J Cancer Res Clin Oncol. 2010; 136(11):1737-43

36. Zhang CM, Brat DJ. Genomic profiling of lower-grade gliomas uncovers cohesive disease groups: implications for diagnosis and treatment. Chin J Cancer. 2016:35:12.

37. Zhang X, Lv QL, Huang YT, Zhang LH, Zhou HH. Akt/FoxM1 signaling pathway-mediated upregulation of MYBL2 promotes progression of human glioma. J Exp Clin Cancer Res. 2017;36(1):105.

38. Hochegger H, Takeda S, Hunt T. Cyclin-dependent kinases and cell-cycle transitions: does one fit all? Nat Rev Mol Cell Biol. 2008;9(11):910-6.

39. el-Deiry WS, Harper JW, O'Connor PM, Velculescu VE, Canman CE, Jackman J, Pietenpol JA, Burrell M, Hill DE, Wang Y, et al. WAF1/CIP1 is induced in p53-mediated G1 arrest and apoptosis. Cancer Res. 1994; 54(5):1169-74

40. El-Deiry WS. p21(WAF1) mediates cell-cycle inhibition, relevant to Cancer suppression and therapy. Cancer Res. 2016;76(18):5189-91.

41. el-Deiry WS, Tokino T, Velculescu VE, Levy DB, Parsons R, Trent JM, Lin D, Mercer WE, Kinzler KW, Vogelstein B. WAF1, a potential mediator of p53 tumor suppression. Cell. 1993;75(4):817-25.

42. Akin D, Wang SK, Habibzadegah-Tari P, Law B, Ostrov D, Li M, Yin XM, Kim JS, Horenstein N, Dunn WA Jr. A novel ATG4B antagonist inhibits autophagy and has a negative impact on osteosarcoma tumors. Autophagy. 2014; 10(11):2021-35.

43. Poillet-Perez L, Xie X, Zhan L, Yang Y, Sharp DW, Hu ZS, Su X, Maganti A, Jiang C, Lu W, et al. Autophagy maintains tumour growth through circulating arginine. Nature. 2018;563(7732):569-73.

44. Apel A, Herr I, Schwarz H, Rodemann HP, Mayer A. Blocked autophagy sensitizes resistant carcinoma cells to radiation therapy. Cancer Res. 2008; 68(5):1485-94

45. Tran E, Chow A, Goda T, Wong A, Blakely K, Rocha M, Taeb S, Hoang VC, Liu SK, Emmenegger U. Context-dependent role of ATG4B as target for autophagy inhibition in prostate cancer therapy. Biochem Biophys Res Commun. 2013:441(4):726-31.

46. Andaloussi AE, Habib S, Soylemes G, Laknaur A, Elhusseini H, Al-Hendy A, Ismail N. Defective expression of ATG4D abrogates autophagy and promotes growth in human uterine fibroids. Cell Death Discov. 2017;3:17041.

47. Fu Y, Hong L, Xu J, Zhong G, Gu Q, Gu Q, Guan Y, Zheng X, Dai Q, Luo X, et al. Discovery of a small molecule targeting autophagy via ATG4B inhibition and cell death of colorectal cancer cells in vitro and in vivo. Autophagy. 2018;20:1-17.

48. Liu PF, Tsai KL, Hsu CJ, Tsai WL, Cheng JS, Chang HW, Shiau CW, Goan YG, Tseng $\mathrm{HH}$, Wu CH, et al. Drug repurposing screening identifies Tioconazole as an ATG4 inhibitor that suppresses autophagy and sensitizes Cancer cells to chemotherapy. Theranostics. 2018;8(3):830-45.

49. Wu Y, Ni Z, Yan X, Dai X, Hu C, Zheng Y, He F, Lian J. Targeting the MIR34C5p-ATG4B-autophagy axis enhances the sensitivity of cervical cancer cells to pirarubicin. Autophagy. 2016;12(7):1105-17.

50. Agrotis A, Pengo N, Burden JJ, Ketteler R. Redundancy of human ATG4 protease isoforms in autophagy and LC3/GABARAP processing revealed in cells. Autophagy. 2019:15(6):976-97.

51. Mathew R, Kongara S, Beaudoin B, Karp CM, Bray K, Degenhardt K, Chen G, Jin S, White E. Autophagy suppresses tumor progression by limiting chromosomal instability. Genes Dev. 2007;21(11):1367-81.

52. Mathew R, Karp CM, Beaudoin B, Vuong N, Chen G, Chen HY, Bray K, Reddy A, Bhanot G, Gelinas C, et al. Autophagy suppresses tumorigenesis through elimination of p62. Cell. 2009;137(6):1062-75.

53. Kongara S, Kravchuk O, Teplova I, Lozy F, Schulte J, Moore D, Barnard N, Neumann CA, White E, Karantza V. Autophagy regulates keratin 8 homeostasis in mammary epithelial cells and in breast tumors. Mol Cancer Res. 2010;8(6):873-84.

54. Tal MC, Sasai M, Lee HK, Yordy B, Shadel GS, Iwasaki A. Absence of autophagy results in reactive oxygen species-dependent amplification of RLR signaling. Proc Natl Acad Sci U S A. 2009;106(8):2770-5.

55. Lee SY. Temozolomide resistance in glioblastoma multiforme. Genes Dis. 2016:3(3):198-210

56. Kanzawa T, Bedwell J, Kondo Y, Kondo S, Germano IM. Inhibition of DNA repair for sensitizing resistant glioma cells to temozolomide. J Neurosurg. 2003;99(6):1047-52.

57. Agnihotri S, Burrell K, Buczkowicz P, Remke M, Golbourn B, Chornenkyy $Y$, Gajadhar A, Fernandez NA, Clarke ID, Barszczyk MS, et al. ATM regulates 3-
methylpurine-DNA glycosylase and promotes therapeutic resistance to alkylating agents. Cancer Discov. 2014;4(10):1198-213.

58. Lo Dico A, Martelli C, Diceglie C, Lucignani G, Ottobrini L. Hypoxia-inducible factor-1alpha activity as a switch for glioblastoma responsiveness to Temozolomide. Front Oncol. 2018;8:249.

\section{Publisher's Note}

Springer Nature remains neutral with regard to jurisdictional claims in published maps and institutional affiliations.
Ready to submit your research? Choose BMC and benefit from:

- fast, convenient online submission

- thorough peer review by experienced researchers in your field

- rapid publication on acceptance

- support for research data, including large and complex data types

- gold Open Access which fosters wider collaboration and increased citations

- maximum visibility for your research: over $100 \mathrm{M}$ website views per year

At BMC, research is always in progress.

Learn more biomedcentral.com/submissions 